\title{
Students' Perceptions of Excellence in Chilean High-Performing Public Schools
}

\author{
Maria Luísa Quaresma ${ }^{1 *}$, Claudio Allende ${ }^{2,3}$, Cristóbal Villalobos $^{4}$ and Sebastián Araneda ${ }^{2}$ \\ ${ }^{1}$ Instituto Iberoamericano de Desarrollo Sostenible, Universidad Autónoma de Chile, Región Metropolitana, Chile, ${ }^{2}$ Center for \\ Advanced Research in Education, Institute of Education, Universidad de Chile, Santiago, Chile, ${ }^{3}$ School of Psychology, Pontificia \\ Universidad Católica de Valparaíso, Valparaíso, Chile, ${ }^{4}$ Centro de Estudios de Políticas y Prácticas en Educación, Pontifical \\ Catholic University of Chile, Santiago, Chile
}

OPEN ACCESS

Edited by:

Antonio P. Gutierrez de Blume, Georgia Southern University, United States

Reviewed by: Noemi Cinelli,

University of La Laguna, Spain Abraham Flanigan, Georgia Southern University, United States

*Correspondence: Maria Luísa Quaresma marialuisa.rocha@uautonoma.cl

Specialty section: This article was submitted to Educational Psychology, a section of the journal Frontiers in Education

Received: 28 June 2021 Accepted: 13 December 2021 Published: 16 February 2022

Citation:

Quaresma ML, Allende C, Villalobos C and Araneda S (2022) Students' Perceptions of Excellence in Chilean High-Performing Public Schools. Front. Educ. 6:732295. doi: 10.3389/feduc.2021.732295
This paper aims to analyze how students attending six of the most prestigious, selective, and high-performing public schools in Chile perceive the concept of excellence and what factors influence their perceptions. A survey was administered to 1,828 students enrolled in $11^{\text {th }}$ and $12^{\text {th }}$ grade. The results show that students share a multidimensional idea of excellence. Five dimensions are identified but, according to students' perceptions, there were two constructs that stood out the most: "effort and self-improvement" and "social commitment and thoughtfulness." We find that variables such as expectations about the future and perceptions about schools explain the dissimilar ideas of excellence shared by students. This research gives voice to students on a current topic of the educational agenda -the concept of excellence- and invites researchers to re-think this construct from perspectives other than academic achievements

Keywords: excellence, goals and value orientation, high-performing public schools, Chile, students' achievement

\section{INTRODUCTION}

High-Performing Public Schools (HPPS) are an important tool to enhance public education for various educational systems worldwide. Since their implementation during the twentieth century, these schools have had sought to transmit national ideals and promote high levels of knowledge for all social classes (Serrano et al., 2012; Valenzuela and Allende, 2012). In general, research on those schools highlights the importance of HPPS in providing an education of excellence to the most talented students to confront and overcome social inequality (Bailey et al., 2012; Matthews and Dai, 2014; Plucker and Callahan, 2014). One of the main expressions of these discussions has been the boom of highly selective schools in the United States (Finn and Hockett, 2012).

Several studies have investigated the effects of this type of school. One body of research focuses on the relationship between self-concept and academic performance in HPPS (Wolff et al., 2018; Sewasew and Schroeders, 2019). However, there is no conclusive evidence on the direction of the relationship between these two variables (Sánchez and Peralta, 2003). Moreover, the evidence on the impact of HPPS on students' self-concept is under debate. On the one hand, drawing on the notion that self-concept is constructed from a continuous process of comparison with classmates (Marsh and Parker, 1984; Seaton et al., 2010), various researchers have indicated that high-achieving students in high-achieving schools have more negative self-concepts. This is a result of comparing themselves to more able students (Huang, 2011; Marsh et al., 2014), which is an effect also called BFLPE (Big-Fish-Little-Pond-Effect). On the other hand, as BIRGE (Basking-In-Reflected-GloryEffect) or the assimilation effect hypothesizes, self-concept could be enhanced if students are enrolled 
in schools with high social status, contributing to their sense of pride, and consequently, to their positive self-concept (Müller and Zurbriggen, 2016).

Another set of research studies discuss the added value that high-performing schools deliver to their students. Some studies measure the effect that these schools have on the academic trajectory of their students, the role of the selective admissions process, and the relevance of family background in successful academic careers (Angrist and Rokkanen, 2015; Allensworth et al., 2016; Barker and Hoskins, 2017). The results show that, in general, HPPS provide little or no added value, primarily in developed countries. In the United States, as well as in England (Clark, 2010), students attending these schools did not achieve better results in standardized tests or at most they achieved a little improvement on their academic results (Allensworth et al., 2016). Dobbie and Fryer (2014) also find evidence of a small impact of attending these schools in United States on college enrollment and college graduation. However, in developing countries such as Mexico (Dustan, 2010), Trinidad and Tobago (Jackson, 2010) and Chile (Bucarey et al., 2014), HPPS do have a positive effect, namely in scores obtained in the national examinations at the end of secondary education and in labor market outcomes.

Finally, various studies analyze the characteristics of students within HPPS (Neild, 2004; Peters and Engerrand, 2016). Results evidence that most high-achieving students with low incomes do not apply to selective schools, and that, in many cases, social minorities and vulnerable populations (e.g., the case of Hispanics /Latinos and African Americans in the United States) are underrepresented in these schools (Neild, 2004; Wright et al., 2017). This evidence questions the role that these schools play in social mobility and the reduction of inequalities.

Chile has fostered the creation of HPPS. These schools have a long tradition of excellence and a strong anchorage in the republican ideals (Fercovic, 2020). They represent the main path to elite universities and to the main social positions of power and prestige (Serrano, et al., 2012). While some studies on these schools have identified them as spaces where social mobility can be promoted (Ruiz, 2010), other researchers have shown that HPPS deliver little added value to their students, and that they are attended mainly by middle and high-class Chilean students (Allende, 2015).

The study of the notions of excellence, especially in the educational field, has been related to political and philosophical discussions on social justice, talent, meritocracy, and equal opportunities (Aubert and Gaulejac, 1991), central aspects in the configuration of HPPS. Studies on excellence have tended to focus on higher-education environments and on educational policies, leaving behind school contexts and relegated community perceptions (Gopinathan and Lee, 2018). Meanwhile, the few studies on students' perceptions in gifted student education contexts have focused on the satisfaction they feel for belonging to their schools (Matthews and Kitchen, 2007). Hence, the evidence on the notions of excellence shared between gifted school communities is rare and matters mainly for three reasons. Firstly, it allows us to understand how students and teachers are making sense of this key concept within neoliberal educational policies and how they are reappropriating it as more than just academic performance. Secondly, understanding students' subjectivities can be an important tool for policy makers who should pay attention to "real schools" and should listen to students and teachers' perceptions instead of imposing "a theory from above" (Ball et al., 2012, p.149). Lastly, in an educational system as highly competitive and market oriented as Chile's, it is relevant to know if students share a negative perception of excellence related to stress or, on the contrary, if they perceive it as a positive concept linked to the mainstream meritocratic vision of success based on effort and hard work.

Despite this evidence on HPPS, it is hard to find literature focused on HPPS and students' perceptions of excellence. Thus, it seems relevant to study the concept of excellence that is generated within these schools and that is shared by these students.

Our main thesis states that the social representations of excellence shared by students attending HPPS in Chile present a multidimensional configuration of excellence not restricted to academic dimensions, in line with a holistic perspective of education and a goal of educating the whole person. We argue this for two reasons. Primarily, HPPS students in Chile are often part of social and/or political movements, and HPPS schools often have curriculums not restricted to training students according to national standards and national examinations. Secondly, these students are socialized around the ethical ideal of 'constant improvement', wanting to achieve the 'ideal student' model, which is even more complex and difficult to accomplish than academic performance.

The main objective of this research is to explore students' perceptions of excellence in high-performing public secondary schools in Chile, through the following two research questions: 1) What are students' perceptions of excellence, and 2) What are the factors related to these perceptions of excellence? To answer these questions, this study performed a quantitative explorative analysis based on a questionnaire applied to students belonging to a set of public high-performing high schools within Chile's Metropolitan Region. Questionnaire results were then analyzed with multivariate analysis methods.

This article is divided into four parts, aside from this introduction. First, the notion of 'excellence' is conceptually described and analyzed, contextualized within the general Chilean educational system and HPPS in Chile. The methodology used is then detailed, elaborating on the sample, instrument and data analysis methods used. The fourth section analyzes the main results of the study, describing the sociodemographic characteristics of the interviewees, the various dimensions of the concept of excellence obtained from the analysis and the variables that are positively or negatively related to each of these dimensions. Lastly, the conclusions reflect on the relevance of this research on HPPS for public policy and knowledge in the educational field.

\section{CONCEPTUAL AND CONTEXTUAL BACKGROUND \\ The Concept of Excellence: A State of the Art}

The concept of excellence has become an important topic of discussion in the last decades (Hartley, 2006), raising multiple 
discussions on its definition. Duru-Bellat and Mingat (2011), who propose the existence of multiple dimensions of excellence, establish one interesting approach. For these authors, excellence may concurrently be understood as a measure related to the level of grades obtained by the students, as a concept related to cognition, values and abilities transmitted by the school, as an assessment of the career during or after schooling, and/or as an aspect of performance of some or all the students within an educational system.

From a similar perspective, Gillies (2007) suggests a definition of excellence based on three notions: $n$-excellence, $i$-excellence, and c-excellence. In the first case, excellence is norm-referenced, which qualifies as 'excellent' not only those who surpass this norm, but also those who achieve the highest and the best in relation to the norm. I-excellence is related to educational improvement based on personal performance rather than general criteria. Lastly, c-excellence is related to the general criteria of achievement, which are theoretically available to everyone. Another interesting distinction, although more focused on the individual perspective, is the one proposed by MacAllister et al. (2013). According to these authors, it is possible to conceive three different meanings of excellence: excellence as performance that surpasses others,' excellence as the progress related to previous own performances, and excellence as the fostering of high levels of good personal qualities (virtues).

Regardless of their endorsement, all these definitions tend to center the dimensions of excellence on academic and valuerelated elements, focusing on the capabilities of the students and on the method in which their talents should be categorized. Nevertheless, excellence may also be measured through a dimensional plurality that goes beyond these cognitive aspects, where it can be perceived as a complex construct based on social competence and the students' areas of interest (Van Avermaet et al., 2011). Consequently, it is important for school systems to recognize at least two big aspects or components of excellence: excellence as the core knowledge common to all students, and 'differential excellence,' based on abilities that each student develops according to their talents.

The development of this holistic vision of excellence has two important implications. On one hand, it develops a notion of excellence which simultaneously considers academic, artistic, socioemotional and value-related elements (Berger, 2003). This promotes dimensions that surpass the traditional limited approach restricted solely to cognitive aspects. On the other hand, this vision combines universal and personal conceptions, understanding excellence both as a shared and personal goal of achievement, prioritizing a holistic development of students' abilities.

\section{The Chilean School System and High-Performing Public Schools}

From an international point of view, the Chilean school system is atypical. Organized around a model of competition, financed mainly by a system of universal voucher, and sustained through a robust compliance organization, this educational system can be understood as an extreme example of market logic applied to the educational field (Villalobos and Quaresma, 2015). One of the most important effects of this model has been the reduction in the role and value of the public sector. Within a period of 30 years, student enrollment in public education has been reduced from around $70 \%$ (Bellei et al., 2010) to $38 \%$ in $2018^{1}$. In this context, HPPS have managed to still be considered paragons of public education, despite their diminished role, enrollment, and available resources. One of the policies that make this feasible is the possibility for some schools to select the best students and gifted children.

A High-Performing Public School in Chile, in general terms, can be distinguished from other public high schools in five ways. First, these establishments were, in general, founded at the beginning or middle of the twentieth century and developed an important role in the historical educational tradition of Chilean elites. A second, related characteristic of these schools is their social recognition. According to the $4^{\text {th }}$ article of the Supreme Decree of Education $N^{\circ} 680$ from 2008, a school is recognized as a Traditional HPPS "having fulfilled a historical role or being in full possession of social recognition," therefore emphasizing the symbolic function of these establishments. Third, these schools count with high levels of academic performance in national rankings and university standardized tests, generating results that match or surpass those of private schools (Allende, 2015). Fourth, an important part of these establishments has selective admission, contrary to most public schools (Godoy et al., 2014). And fifth, these schools have played historic roles in social and school movements, especially in those of 2006 and 2011, which culminated with the 2019 social protest.

In recent years, most HPPS in Chile have experienced a reduction in enrollment ${ }^{2}$ a drop in their national examinations and university selection test scores, and a loss of public prestige. Many hypotheses could explain this low enrollment: the central role of HPPS students in the 2006, 2011 and 2019 protests, the long-lasting strikes in many of these schools, the changes in educational policy that have increased the choices available to families, the common HPPS budget reductions, which have not allowed for educational experimentation or substantial pedagogical improvements, and the creation of other selective schools by the government since 2011 (called Bicentennial Schools). Despite these difficulties, HPPS continue to be a relevant space for educational policy analysis for at least three reasons. Firstly, HPPS are still a treasured part of Chilean public education, both for their tradition and for their students' academic results. Secondly, discussions on the importance of HPPS have reignited in the past few years, especially because the 2019 social outbreak placed the role of public education at the center of the debate around overcoming social inequalities. Lastly,

${ }^{1}$ Information available on The World Bank website: https://data.worldbank.org/ indicator/SE.SEC.PRIV.ZS

${ }^{2}$ This process has been so intense that, for example, in the most prestigious HPPS for boys in Chile, which used to have 2,000 to 3,000 applicants for 600 or 700 vacancies, in 2020 only 780 students applied for the 600 places offered (Delgado, 2019). 
studying HPPS allows us to understand the relationship between merit, excellence and social mobility, particularly because large part of the economic and political elites of the country were formed in these establishments. This is why it is of paramount importance to give HPPS students a voice and listen to their perceptions of such a central concept as excellence when defining public educational policy.

\section{METHODS}

This section presents the main methods used in this investigation. First, we describe the sample used, then we describe the main stages of survey development and validation, and finally we describe the statistical procedures used in this investigation.

\section{Sample}

The research was conducted in late 2015at six public schools recognized as High-Performing Public Schools, in the Santiago Metropolitan Region. These schools were selected on the basis of seven operational criteria: 1) at least 50 years of existence; 2) socially recognized for their prestige; 3 ) an institutional mission statement focusing on the ideals 'sense of school belonging' and "academic achievement"; 4) ranked in the top 20 average performance of public schools in the University Selection Test (PSU) in the last 5 years; 5 ) admission processes based on a strict academic selection criteria (previous academic results and scores in Reading and Mathematics entrance examinations), and on personal interviews with students and parents; 6) different gender compositions (coeducational, all-male, all-female); 7) provide only Scientific-Humanist curriculum, rather than vocational and technical curriculums that elite students rarely choose.

According to those criteria, we selected six High-Performing Public Schools. Three are boys-only, two are girls-only and one is coeducational. Four provide educational coverage from $7^{\text {th }}$ to $12^{\text {th }}$ grade, one from $9^{\text {th }}$ to $12^{\text {th }}$ grade, and one provides education for primary $\left(1^{\text {st }}-8^{\text {th }}\right.$ grade $)$ and secondary $\left(9^{\text {th }}\right.$ to $12^{\text {th }}$ grade $)$ students. Some of these schools have deep historical roots dating back to Chile's independence. In the SIMCE ${ }^{3}$ and $\mathrm{PSU}^{4}$ standardized tests between 2009 and 2014, the average SIMCE test score of the six selected schools was almost 302 points in reading and 333 points in math, compared to the national average of about 250 points for both tests and to elite private school scores averaging 287 points in reading and 317 points in math. In the PSU, the selected schools obtained an average of 634 points in the language test and 640 points in the math test. For the same period, the national average was 497 points in language and 502 points in math, while elite private schools averaged 613 points in language and 631 points in math. If we consider excellence solely by

${ }^{3}$ SIMCE is a national test administered by the Ministry of Education, which evaluates academic achievement in reading and mathematics. It is applied every year to $4^{\text {th }}$ grade students and in alternate years to $6^{\text {th }}, 8^{\text {th }}$ and $10^{\text {th }}$ graders. ${ }^{4} \mathrm{PSU}$ is the national university selection test taken every year by students graduated from $12^{\text {th }}$ grade aiming to enter to the most selective colleges of the country. measuring pupils' attainment on standardized tests, these six schools were indeed high performing.

In order to learn about the students' perceptions of excellence, a self-administered questionnaire was applied $(N=1,828)$ to students of the last 2 years of High School Education $\left(11^{\text {th }}\right.$ and $12^{\text {th }}$ grades) in 2015. Those students were selected for their greater age maturity and longer academic career, and also for their greater competence to answer conceptual questions that require greater levels of thoughtfulness. Because each of the six schools had several forms or classes per level, a random selection was conducted with a maximum of 12 classes in each school. Once we selected the classes, the questionnaire was administered to all students on one, specific day between May and August of 2015 .

\section{Instrument}

The questionnaire ${ }^{5}$ is organized into several sections to capture the main sociological student characteristics that are essential to better understand the plurality of perceptions around the holistic concept of excellence (Berger, 2003), and to analyze how those variables are related to those perceptions. So, this questionnaire provides us information about who these students are (their academic experiences and sociocultural background), how they perceive their school, their future, the meanings of public education and the main educational policies being implemented in Chile and, lastly, how they perceive excellence.

As has been pointed out, if we follow the theoretical approach to excellence as a complex concept (Gillies, 2007; Duru-Bellat and Mingat, 2011; Van Avermaet et al., 2011; MacAllister et al., 2013) related to a plurality of variables (namely, socio-demographic ones), it is necessary to take in account all those questionnaire dimensions, analyzing students' experiences, points of views and critical thinking. Moreover, the questionnaire is the quantitative technique that best allows us to capture those relationships and statistical analysis has been used in several studies on excellence (Duru-Bellat and Mingat, 2011).

Based on the dimensions analyzed in previous research on excellence (Aubert and Gaulejac, 1991; Berger, 2003; Gillies, 2007; Duru-Bellat and Mingat, 2011) and taking into consideration the particularities of the Chilean context (Bellei, 2015), we constructed 15 items (using a four point Likert scale, $1=$ strongly disagree, 2 = disagree, $3=$ agree and $4=$ strongly agree) aiming to represent the main perceptions on academic excellence (see Table 1). In line with the holistic approach to education focused on the whole person that was discussed above, we included alternatives related to academic, social and civic dimensions of excellence, as well as individual and collective perspectives. These several dimensions of the concept of

${ }^{5}$ The research effort included 24 focus group discussions with students before the elaboration and application of the questionnaire. These focus groups covered various topics related to excellence: their perceptions on this concept, their student practices to achieve success, and their school experiences, among others. The information gleaned supported the construction of the instrument and contributed to the study's general results. However, this article only addresses the quantitative analysis of the concepts of excellence gained from the administered questionnaire, without venturing into the subjective perceptions gathered from the focus groups 
TABLE 1 | Factor loadings for varimax-rotated factor analysis of Notions on Excellence.

\begin{tabular}{|c|c|c|c|c|c|}
\hline Variable & Factor1 & Factor2 & Factor3 & Factor4 & Factor5 \\
\hline a.- Being top of the class & 0.7453 & & & & \\
\hline b.- Enrolling in the best college/university in the country & 0.8229 & & & & \\
\hline C.- Studying for many hours & 0.5899 & & & & \\
\hline d.- Studying a prestigious degree & 0.6712 & & & & \\
\hline e.- Living with stress and anxiety & & 0.8636 & & & \\
\hline f.- Not spending time with friends/giving up leisure activities & & 0.8784 & & & \\
\hline g.- Limitless effort & & & & & 0.4177 \\
\hline h.- Doing nothing but studying & & 0.727 & & & \\
\hline i.- Not settling for having a degree or profession and pursuing further studies & & & & & 0.4284 \\
\hline j.- Living in a country with equal opportunities for everyone & & & 0.5624 & & \\
\hline k.- Being critical and thoughtful & & & 0.7702 & & \\
\hline I.- Being smart & & & 0.4431 & & \\
\hline m.- Observing school regulations without complaint & & & & 0.6078 & \\
\hline n.- Only studying the scientific knowledge taught by the school & & & & 0.6022 & \\
\hline o.- Learning for the sake of knowledge & & & 0.5691 & & \\
\hline
\end{tabular}

Source: Compiled by the authors

excellence were adapted from sociological studies developed by Duru-Bellat and Mingat (2011), Gillies (2007), MacAllister et al. (2013) and Berger (2003).

Validation of this survey was performed in three stages. First, a pilot test was conducted on two schools $(N=630)$, where we received student comments on specific questions. Second, a review of the individual items by three experts (Chilean and international researchers in Sociology and Educational Sciences) was conducted. Lastly, the internal consistency of the items was analyzed. The items related to the different dimensions of excellence obtained a consistency of $\alpha=0.73$, which, according to Hair et al. (2010), is acceptable for an exploratory factor analysis (EFA).

The questionnaire also includes questions about the students' academic life and future projects, their perceptions about the mission of public education, their opinions about their current school, their extracurricular activities, and finally their sociodemographic characterization. These variables allow us to better characterize the students and understand their multidimensional concepts of excellence.

\section{Procedure}

In order to analyze the concept of excellence, a series of indices were constructed at the student level to capture various notions on excellence. The indices were constructed in three stages. First, Cronbach's Alpha was estimated, verifying that the selected variables obtained a reliable result. Subsequently, we applied an exploratory factor analysis (EFA) using a principal axis factor with varimax rotation. We used this rotation because the correlation matrix for the estimated factors remains nearly orthogonal when using an oblique rotation (Tabachnick and Fidell, 2007, p.646). As an extraction method, we used a principal factors method fostered by the rejection of all multivariate normal distribution tests applied. Additionally, given that all variables were categorical, we used a polychoric correlation matrix to obtain robust estimations. The number of factors was determined via parallel analysis (Humphreys and Monatelli, 1975) and variables with factor loadings over 0.4 were selected to each retained factor. Considering the rules of thumb proposed by Hair et al. (2010), it could be considered an acceptable level for interpretation of the data structure. Table 1 shows the factor loadings.

Lastly, the Kaiser-Meyer-Olkin (KMO) test delivered a value of 0.8 and Bartlett's test of sphericity rejected the null hypothesis. Both tests allow us to check the quality of our factorial analysis, showing that our data is be suitable for factor analysis and that the model was highly satisfactory (Hair et al., 2010).

The indices (factor scores) generated were obtained through a weighted average of the selected variables for each factor. The weighting criteria were obtained through the percentage of the variance explained by each variable within each factor (Table 2), which was rescaled for each factor in order to sum 1 . This methodology corresponds to a non-refined method to estimate factor scores (DiStefano et al., 2009). In this case, it was determined to be a good strategy because it allows us to use the variables in one index at a time. The constructed indices were set on a scale from 1 to 4 , where 1 represents the lowest degree of association by the students regarding the value of the index, and 4 the highest.

Subsequently, in order to establish perception of excellence levels, we applied a K-Mean non-hierarchical clustering analysis with randomly selected initial values (Tryfos, 1998), dividing each index into four groups to analyze information in a similar way to the originally-used Likert scale.

Finally, we established the determinants of the different constructions that represent notions on excellence. In order to estimate the determinants of the notions on excellence perceived by the students, we estimated hierarchical random intercepts models. However, the LR test could not reject the null hypothesis of no random intercept for all estimated models (Model 1: X2 (1, $N=1,529)=0.1, p=0.376$; Model 2: $X 2(1, N=1,545)=4.1 \mathrm{e}-12$, $p=1.0$; Model 3: $X 2(1, N=1,531)=1.8 \mathrm{e}-12, p=1.0$; Model 4: $X 2$ $(1, N=1,545)=0.62, p=0.216:$ Model 5: $X 2(1, N=1,537)=0.00$, $p=1.0)$. Given those results, we can use ordinary least squares, as multilevel models do not provide any additional value to the estimation (Rabe-Hesketh and Skrondal, 2008). 
TABLE 2 | Estimated weights for indices related to notions of excellence.

\begin{tabular}{|c|c|c|c|}
\hline & & Variable & Weight (\%) \\
\hline \multirow[t]{4}{*}{ Index 1} & Excellence as academic development & d.- Studying a prestigious degree & 22.2 \\
\hline & & c.- Studying for many hours & 17.1 \\
\hline & & b.- Enrolling in the best college/university in the country & 33.3 \\
\hline & & a.- Being top of the class & 27.3 \\
\hline \multirow[t]{3}{*}{ Index 2} & Excellence as feeling stressed and giving up social life & h.- Doing nothing but studying & 25.8 \\
\hline & & f.- Not spending time with friends/giving up leisure activities & 37.7 \\
\hline & & e.- Living with stress and anxiety & 36.5 \\
\hline \multirow[t]{4}{*}{ Index 3} & Excellence as social commitment and thoughtfulness & o.- Learning for the sake of knowledge & 22.6 \\
\hline & & I.- Being smart & 13.7 \\
\hline & & k.- Being critical and thoughtful & 41.5 \\
\hline & & j.- Living in a country with equal opportunities for everyone & 22.1 \\
\hline \multirow[t]{2}{*}{ Index 4} & Excellence as conformity & n.- Only studying the scientific knowledge taught by the school & 49.5 \\
\hline & & m.- Observing school regulations without complaint & 50.5 \\
\hline \multirow[t]{2}{*}{ Index 5} & Excellence as effort and self-improvement & i.- Not settling for having a degree or profession and pursuing further studies & 51.3 \\
\hline & & g.- Limitless effort & 48.7 \\
\hline
\end{tabular}

Source: Compiled by the authors.

As dependent variables, we used a set of indices representing the different notions on excellence, and we considered a set of variables related to the school and individual characteristics as explanatory variables. Within individual (personal) variables, we include gender, age, grade, grade retention, number of siblings that studied in the same school, mother's educational attainment, number of books at home, and two variable groups. One set of variables represents the students' life prospects: being happy regardless of their profession, having a stimulating and socially-recognized profession, raising a family with children, taking part in the country's politics, taking part in social interventions, living a life without projects, achieving affective fulfillment, and working on self-improvement/trying to be the best. The other variable set relates to the students' extracurricular activities: political or social participation, leisure and spending time with the family, reading, and participation in sports. School variables, on the other hand, include a set of student perceptions regarding their current school: school motivates students to think for themselves, school is too obsessed with students' grades, school recognizes students' effort, school motivates students to take part in extracurricular activities, school motivates students to help their schoolmates, school provides students with interesting and motivating classes, and school values student merit and excellence above all else.

\section{RESULTS AND DISCUSSION}

We present the main results in this section, starting with a sociodemographic description of the interviewed students. We then posit the five dimensions of excellence found reflecting on the multidimensional nature of this concept, according to the students' perceptions, and analyze how the results relate to our initial research hypotheses and with current literature on the subject. We conclude by presenting a regression model that allows to analyze the independent variables most closely related to each of the five dimensions of excellence.

\begin{tabular}{lcc}
\hline TABLE 3 | (Selected) descriptive statistics of the sample. & & \\
\hline Variable & Mean & SD \\
\hline Average age & 16.99 & 0.85 \\
Grade $\left(1=12^{\text {th }}\right.$ grade; $0=11^{\text {th }}$ grade) & 0.45 & 0.50 \\
Gender $(1=$ Female; $0=$ Male) & 0.38 & 0.48 \\
Average educational attainment of the father & 14.18 & 3.01 \\
Average educational attainment of the mother & 14.12 & 2.77 \\
Number of books between 11 and 50 & 0.33 & 0.47 \\
Number of books greater than 50 & 0.58 & 0.49 \\
Former school setting: Private Non-Subsidized & 0.06 & 0.24 \\
Former school setting: Private Subsidized & 0.52 & 0.50 \\
Application to another public school (1 = Yes, 0 No) & 0.54 & 0.50 \\
From which grade is he/she in the school (7th grade) & 0.58 & 0.49 \\
From which grade is he/she in the school (9th grade) & 0.33 & 0.47 \\
Has repeated a year (1 = Yes; $0=$ No) & 0.22 & 0.42 \\
Educational attainment prospect: Graduate Degree & 0.32 & 0.47 \\
Educational attainment prospect: Master's Degree & 0.20 & 0.40 \\
Educational attainment prospect: Doctoral Degree & 0.19 & 0.40 \\
Educational attainment prospect: Post-doctoral Degree & 0.26 & 0.44 \\
Number of Observations (average) & 1.758 & \\
\end{tabular}

Source: Compiled by the authors

\section{High-Performing Public Schools Student Characteristics}

Table 3 shows the main descriptive results related to the sociodemographic characteristics of HPPS students. The sample comprises 11th grade students $(45 \%)$ and 12th grade students $(65 \%)$ with an average age of $17(\mathrm{M}=16.9, \mathrm{SD}=0.85)$. Additionally, that most of the respondents $(\mathrm{M}=0.58, \mathrm{SD}=0.49)$ attend their respective schools since seventh grade, which is the foundational entry point for almost all of the studied schools (five out of six). A more reduced number of students enrolls halfway through their school career, i.e., in 9th grade $(\mathrm{M}=0.33$, $\mathrm{SD}=0.47)$.

In line with Allende (2015), it is possible to see that, on average, the students' parents have high educational attainment levels $(\mathrm{M}=14.18, \mathrm{SD}=3.01$ for fathers; 
TABLE 4 | Estimated indices, interpretation and percentage of students that agree or strongly agree on the notion of excellence.

Topic

Factors

$\%$ of students

that agree or

strongly agree

Notions on excellence

(1) Excellence as academic development

$52 \%$

(2) Excellence as feeling stressed and giving up social life

(3) Excellence as social commitment and thoughtfulness

(4) Excellence as conformity

(5) Excellence as effort and self-improvement

Number of observations
$28 \%$

$57 \%$

$31 \%$

$84 \%$

1.791

Source: Compiled by the authors

$\mathrm{M}=14.12, \mathrm{SD}=2.77$ for mothers) and high levels of cultural capital, measured by books kept in the household greater than 50 $(\mathrm{M}=0.58, \mathrm{SD}=0.49)$. These students' family background is evidently different to that of municipal school students in Chile, who are mainly youngsters from Chilean families with low income and from immigrant families (Castillo et al., 2018). Most of the mothers of students attending Chilean public schools have not completed their high school education (Carrasco et al., 2014). Regarding the international literature, these results are in line with other studies, such as Neild (2004) carried out in the United States, which reveals the low level of enrollment of vulnerable students in HPPS.

Regarding their previous school type, the results show that most of the students come from private subsidized schools $(\mathrm{M}=$ $0.52, \mathrm{SD}=0.50)$ or private non-subsidized schools $(\mathrm{M}=0.06, \mathrm{SD}$ $=0,24)$, similar to the findings by Allende (2015). Therefore, it is possible to infer that the parents who initially opt for private establishments do not definitively dismiss the idea of enrolling their children into public education when the educational quality of the school is guaranteed. So, the profile of these families is similar to that found in international studies, being strongly motivated regarding their children's academic career and willing to make rational and strategic decisions to achieve their educational goals (Van Zanten, 2016).

Finally, it is important to mention that few students have failed the year $(\mathrm{M}=0.22, \mathrm{SD}=0.42)$ and almost all the students in the sample (97\%) have prospects of studying at college/university level. Almost a third of the sample even has the goal to complete a doctorate or post doctorate degree.

In summary, these results show that the students in the sampled schools have privileged sociocultural backgrounds and have set high standards for their futures.

\section{The Concept of Excellence in High-Performing Public Schools Students}

Table 4 shows the five factors constructed from our factor analysis, which seeks to account for the different notions of excellence expressed by the students. This implies that the identified notions are a product of the composition of the data instead of a grouping or previous conceptual selection. Additionally, the table presents the results obtained via the cluster analysis on the indices, which allows us to identify the percentage of the students who agree or not with the construct presented in each index.

The results show that the idea of excellence related to school meritocracy -understood as limitless effort and constant selfimprovement - is shared by $84 \%$ of the students $(\mathrm{M}=0.84, \mathrm{SD}=$ 0.37). Perceptions of excellence such as "Not settling for having a degree and pursing further studies" and "Limitless effort" are those which make more sense to the students, which may be expected from students in high-performing schools who are indoctrinated with ideals of excellence and surpassing their own achievements, as well as students from families with high levels of cultural capital (Raveaud and Van Zanten, 2007).

However, as the literature documents (Moya Díaz and Hernández-Aracena, 2014; Courtois, 2018), education in schools of excellence is not characterized by an exclusive focus on the performance dimension. Therefore, the above-average results of their students are not just a consequence of blinkered training in test performance but rather is related to a holistic formation that encompasses accountability, love of learning or a critical outlook, creating a broad perception of the concept of excellence. It is no surprise, then, that $57 \%$ of students perceive excellence as having non-instrumental dimensions such as social commitment and involvement $(\mathrm{M}=$ $0.57, \mathrm{SD}=0.49$ ). In this regard, perceptions such as "living in a country in which everyone has equal opportunities," "being critical and thoughtful," as well as "being smart" and "learning for the sake of knowledge," are all seen as dimensions of excellence. Regardless of their differences, all these notions point to viewing success in a markedly expressive manner, loosely related to the instrumental dimension. This perception concurs with a greater receptivity to the idea of a holistic education by families with a higher level of cultural capital -such as the families of this study's intervieweeswho look for an education that can guarantee expressive wellbeing, instrumental success and intellectual development for their children (Raveaud and Van Zanten, 2007). This could mark the difference in access to a labor market that is no longer exclusively focused on competing with academic credentials (Brown, et al., 2016). Along the same lines, and in opposition to the more traditional perspective of success as "academic results" (Cress et al., 2010) and what might be expected from this demographic, only $52 \%$ of the students perceive excellence as being related to purely academic concepts $(\mathrm{M}=0.52, \mathrm{SD}=0.50)$. These concepts include school performance ("being top of the class" and "studying 
hard") and post-school achievements ("make it into the best college/university" or be enrolled in a "prestigious college/ university degree").

Another relevant aspect is the low degree of association between excellence and the idea of conformity; in other words, there is little perception of excellence as submission to the norm or limiting learning to what the school dictates $(\mathrm{M}=0.31, \mathrm{SD}=$ 0.46 ). This result might point to the students' critical thinking and altering of the status quo, which might be related to the leading role assumed by HPPS students in the student movement throughout the past decade (UNICEF, 2014; Bellei, 2015) and to the empowerment and critical thinking it fostered in these social actors. It is relevant to mention that the notions related to negative perspectives of excellence found in the literature (Aubert \& Gaulejac, 1991; Perrenoud, 1995) represent the least adhesion among the respondents. Students only relate excellence to stress and to giving up a social life to a lesser extent $(\mathrm{M}=0.28, \mathrm{SD}=$ 0.45). Therefore, expressions such as "living with stress and anxiety," "not spending time with friends/giving up leisure activities" and "doing nothing but studying" are less commonly associated with the concept of excellence. These results differ from the conclusions of some previous studies, which recount the importance of these negative notions for their sample, pointing out that their students perceived excellence as the abnegation of their youth lifestyle and identity (Darmon, 2013) and suffered from depression, anxiety crises or obsessive behavior (Perrenoud, 1995).

As previously mentioned, the LR test could not reject the null hypothesis of no random intercept when multilevel models were applied. This implies the nonexistence of significant differences in terms of variance between schools, which in statistical terms means that the students perceived notions of excellence similarly across sampled schools. Although this does not imply that they hold the same notions, it is possible to say that they share many common aspects.

\section{Factors That Explain the Perceptions of Excellence in High-Performing Public Schools Students}

We estimated factors related to the five identified notions of excellence using an ordinary least squares regression method and five groups of variables (see Table 5): 1) students' personal characteristics; 2) socioeconomic characteristics; 3) personal prospects; 4) extracurricular activities y; 5) school perceptions of students. The fit of the models (r-square) is better in profile 1 (academic development), profile 3 (social commitment and thoughtfulness) and profile 4 (conformity). In profiles 2 (feeling stressed and giving up social life) and 5 (excellence as effort and self-improvement), the fit of the model is lower.

In order to understand students' perceptions on excellence, it is necessary to analyze each group of variables separately. Regarding students' personal characteristics, having previously attended "private non-subsidized schools" has a positive correlation with the construct of excellence as academic development $(\beta=0.12, p \leq 0.01)$ and a negative correlation with excellence as social commitment and thoughtfulness $(\beta=-0.2, \mathrm{p} \leq 0.05)$. This conception diverges with the holistic educational mission of private schools identified by some international researchers (Mension-Rigau, 2007; Quaresma, 2014), who have pointed out that upper classes' private schools do not reduce excellence to mere academic performance, perceiving it as a multidimensional concept. A possible explanation for the correlations identified in this research may be found in the characteristics of Chilean private schools, mostly linked to the Catholic Church (Alarcón, 2017). As part of their educational mission, these institutions implement a skills-based pedagogy model (Madrid, 2016) but adopt silence on citizenship and democratic politics (Cox and Imbarack, 2017).

Gender and grade attended are other variables with relation with students' perception on excellence. Being female and attending $12^{\text {th }}$ grade is positively correlated with excellence as social commitment and thoughtfulness $(\beta=0.07, \mathrm{p} \leq 0.05$, and $\beta=$ $0.12, \mathrm{p} \leq 0.05$, respectively) and negatively correlated with the idea of excellence as academic development $(\beta=-0.10, \mathrm{p} \leq 0.1$, and $\beta=-0.12, \mathrm{p} \leq 0.01$, respectively). On the one hand, in terms of gender dimension, these results confirm differential gender socialization (Bourdieu, 1998), which educates girls mainly in the expressive dimensions of life. On the other hand, the link between excellence and political or social participation is strongly linked to student age; in the 2006 mass student protests in Chile, the main spokespersons of the movement were those who were attending their last year of secondary school (Donoso, 2013). Stress about the costs of the university entry exam, high prices of university tuition and the perception of high levels of educational inequality may explain the last-year-students' social and political participation (Castillo, 2017).

Students' socioeconomic characteristics are not deeply related with students' perceptions on excellence, except for the factor "mothers' educational attainment." This variable has a positive and significant association with the idea of excellence as social commitment and thoughtfulness $(\beta=0.01, p \leq 0.05)$. Another important finding is related to students' cultural capital: "having more than 51 books" decreases the probability of sharing the idea of excellence as academic development $(\beta=-0.14, p \leq 0.1)$. This narrow conception of excellence is not concurrent with the development of dimensions promoted by having books and reading, such as critical and analytical thinking, creativity, knowledge and openness of mind.

Concerning personal prospects, the more instrumental future ideal lifestyles are strongly related to more conservative ideals of excellence. For example, the idea of excellence as conformity has a positive and significant correlation with independent variables related to the desire to have a "high wage and a socially-recognized profession" $(\beta=0.23, p \leq 0.01)$, "to raise a family with children" $(\beta$ $=0.11, p \leq 0.05)$ and to seek "self-improvement and always try to surpass own achievements" $(\beta=0.16, \mathrm{p} \leq 0.05)$. The two former variables are also correlated with the idea of "excellence as academic development" ( $\beta=0.38, p \leq 0.01$ and $\beta=0.16, p \leq$ 0.05 , respectively) which -in line with other international studies (Quaresma, 2014)- presents a negative association with the students' intention to "take part in social intervention initiatives" ( $\beta=-0.08, p \leq 0.01)$ in the future. The last independent variable -to seek "self-improvement and always try 
TABLE 5 | Regression models for indices on the notions of excellence.

Variables

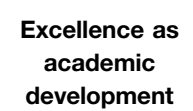

development

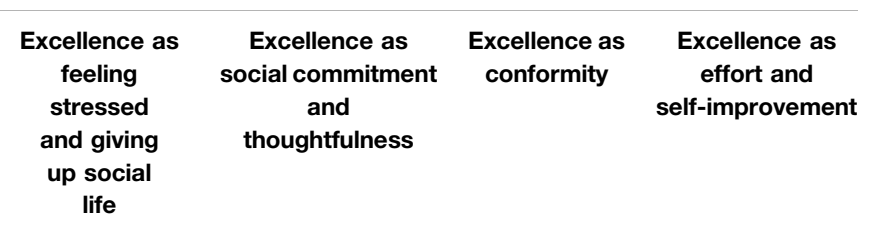

\section{Personal characteristics}

Gender (1 = Female; 0 = Male)

Age (between 15 and 20 years)

Grade $\left(1=12^{\text {th }}\right.$ grade; $0=11^{\text {th }}$ grade $)$

Former school setting: Private Non-Subsidized

Former school setting: Private Subsidized

Has repeated a year (1 Yes; 0 No)

\section{Socioeconomic characteristics}

Between 11 and 50 books

More than 51 books

Educational attainment of the mother (1-21 years)

No sibling has studied here

A sibling studies or has studied here

Personal prospects

Being happy, regardless of my profession

Stimulating job and personal satisfaction

High wage and socially-recognized profession

Raising a family with children

Taking part in the country's politics

Taking part in social interventions

Living life, without projects

Affective fulfillment

Self-improving and trying to surpass own achievements

\section{Frequently-conducted extracurricular activities}

Political or social participation

Leisure and spending time with the family

Reading

Sports

\section{Current school perceptions}

They motivate me to think for myself

They are too obsessed with students' grades

They recognize my efforts
0.04

(0.03)

$-0.12^{\star \star \star}$

(0.01)

$0.12^{\star \star \star \star}$

(0.03)

0.03

(0.04)

$-0.03$

(0.06)

$-0.09$

(0.11)

$-0.14^{*}$

(0.06)

$-0.00$

$(0.00)$

$-0.13$

(0.08)

$-0.05$

(0.09)

$-0.17$

(0.14)

0.28

(0.19)

$0.38^{\star \star \star}$

(0.02)

$0.16^{\star \star}$

(0.06)

$-0.01$

(0.05)

$-0.08^{\star \star \star}$

(0.01)

$-0.07$

(0.06)

$-0.01$

(0.03)

0.00

(0.10)

$-0.09$

(0.07)

$0.27^{\star \star}$

(0.10)

0.02

(0.04)

$-0.00$

(0.04)

0.04

(0.04)

0.04

(0.02)

0.02

(0.04)
$-0.02$

(0.03)

0.05

(0.04)

$-0.08$

(0.05)

0.03

(0.06)

0.01

(0.03)

0.01

(0.06)

$-0.08$

(0.09)

$-0.12$

(0.08)

$-0.00$

(0.00)

0.01

(0.05)

0.05

(0.04)

$-0.22$

(0.14)

$-0.00$

(0.10)

0.06

(0.04)

$-0.02$

(0.05)

$-0.05^{\star}$

(0.03)

$-0.01$

(0.04)

$0.10^{\text {** }}$

(0.03)

$-0.16^{\text {*ᄎ }}$

(0.04)

$-0.02$

(0.07)

0.04

(0.04)

0.02

(0.19)

$-0.05$

(0.04)

$-0.05$

(0.03)

$-0.07$

(0.05)

$0.15^{\star \star *}$

(0.03)

$-0.02$

(0.03) $0.07^{\star *}$

(0.02)

$-0.00$

(0.03)

$0.12^{\text {* }}$

(0.03)

$-0.20^{\star \star}$

(0.05)

$-0.03$

(0.03)

0.04

(0.04)

0.03

(0.05)

0.04

(0.06)

$0.01^{\text {** }}$

(0.00)

$-0.05$

(0.04)

$-0.02$

(0.06)

$-0.09$

(0.09)

0.16

(0.09)

0.03

(0.03)

$-0.03$

(0.02)

$0.17^{\star \star \star \star}$

(0.02)

$0.14^{\text {*** }}$

(0.02)

0.05

(0.05)

$0.22^{\text {** }}$

(0.07)

0.03

(0.05)

$0.12^{*}$

(0.05)

0.17

(0.10)

$0.07^{\text {*** }}$

(0.02)

$0.06^{*}$

(0.03)

0.06

(0.06)

0.04

(0.03)

$0.05^{\text {** }}$

(0.01)

\section{$-0.01$}

(0.03)

$-0.01$

(0.05)

$-0.08$

(0.05)

0.03

(0.06)

$-0.10^{\star *}$

(0.03)

$-0.05$

(0.05)

0.05

(0.12)

$-0.03$

(0.09)

$-0.00$

(0.01)

$-0.11^{\star}$

(0.05)

0.00

(0.04)

$-0.22^{\star \star}$

(0.06)

$-0.10$

(0.11)

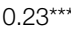

(0.04)

$0.11^{\text {** }}$

(0.03)

$-0.13^{\star}$

(0.05)

$-0.02$

(0.04)

$-0.03$

(0.05)

0.05

(0.05)

$0.16^{\star *}$

(0.06)

$-0.14^{*}$

(0.06)

0.13

(0.10)

$-0.14^{\text {** }}$

(0.04)

0.04

(0.04)

0.05

(0.04)

0.01

(0.04)

$0.12^{*}$

(0.05)

(Continued on following page)

$-0.09$

$(0.05)$

$-0.01$

(0.04)

0.03

(0.04)

$-0.18^{\star}$

(0.09)

$-0.05$

(0.06)

0.02

(0.05)

0.02

$(0.05)$

0.07

(0.09)

0.01

(0.01)

$-0.01$

(0.05)

0.01

(0.07)

$-0.30^{\star \star}$

$(0.09)$

0.08 
TABLE 5 | (Continued) Regression models for indices on the notions of excellence.

\begin{tabular}{|c|c|c|c|c|c|}
\hline Variables & $\begin{array}{c}\text { Excellence as } \\
\text { academic } \\
\text { development }\end{array}$ & $\begin{array}{c}\text { Excellence as } \\
\text { feeling } \\
\text { stressed } \\
\text { and giving } \\
\text { up social } \\
\text { life }\end{array}$ & $\begin{array}{c}\text { Excellence as } \\
\text { social commitment } \\
\text { and } \\
\text { thoughtfulness }\end{array}$ & $\begin{array}{l}\text { Excellence as } \\
\text { conformity }\end{array}$ & $\begin{array}{c}\text { Excellence as } \\
\text { effort and } \\
\text { self-improvement }\end{array}$ \\
\hline \multirow{2}{*}{$\begin{array}{l}\text { They motivate me to take part in extracurricular } \\
\text { activities }\end{array}$} & 0.06 & $0.06^{\star \star}$ & $0.08^{\star \star \star}$ & $0.08^{\star \star}$ & -0.00 \\
\hline & $(0.05)$ & $(0.02)$ & $(0.02)$ & $(0.03)$ & $(0.05)$ \\
\hline \multirow[t]{2}{*}{ They motivate me to assist my schoolmates } & -0.02 & $-0.09^{*}$ & -0.01 & $0.12^{*}$ & -0.00 \\
\hline & $(0.04)$ & $(0.04)$ & $(0.03)$ & $(0.06)$ & $(0.06)$ \\
\hline \multirow[t]{2}{*}{ They provide me with interesting and motivating classes } & 0.01 & -0.04 & 0.02 & $0.08^{\star \star}$ & 0.06 \\
\hline & $(0.06)$ & $(0.04)$ & $(0.02)$ & $(0.03)$ & $(0.04)$ \\
\hline \multirow[t]{2}{*}{ They value merit and excellence above all things } & $0.16^{\star \star \star}$ & $0.08^{\star}$ & 0.06 & 0.09 & $0.09^{\star}$ \\
\hline & $(0.04)$ & $(0.03)$ & $(0.03)$ & $(0.06)$ & $(0.04)$ \\
\hline \multirow[t]{2}{*}{ Constant } & 1.05 & 1.07 & $2.19^{\star \star}$ & $2.31^{\star \star}$ & $1.92^{*}$ \\
\hline & $(0.54)$ & $(0.85)$ & $(0.57)$ & $(0.74)$ & $(0.80)$ \\
\hline Number of Observations & 1,529 & 1,545 & 1,531 & 1,545 & 1,537 \\
\hline$R$-squared & 0.17 & 0.06 & 0.15 & 0.17 & 0.05 \\
\hline
\end{tabular}

Robust standard errors in parenthesis

${ }^{* * *} \mathrm{p}<0.01,{ }^{* *} \mathrm{p}<0.05,{ }^{*} \mathrm{p}<0.1$.

to surpass own achievements"- has a significant and positive correlation with the idea of "excellence as effort and selfimprovement" ( $\beta=0.30, p \leq 0.01)$.

More expressive and socially-engaged prospects have a positive correlation with the idea of excellence as social commitment and thoughtfulness. So, "taking part in the politics of the country" in the future $(\beta=0.17, p \leq 0.01)$, "being involved in social movements" $(\beta=0.14, p \leq 0.01)$ and achieving "affective fulfilment" $(\beta=0.22, p \leq 0.05)$ predicts that expressive perception of excellence. Moreover, the prospect of "(being) happy regardless of the profession" ( $\beta=-0.22, p \leq 0.05)$ is negatively correlated with the idea of excellence as effort and self-improvement, while the idea of "living life without projects" has a positive correlation with excellence as feeling stressed and giving up social life $(\beta=$ $0.10, p \leq 0.05)$.

Extracurricular activities have also an impact on students' perceptions on excellence. "Reading" is an activity that is positively correlated with the construct of excellence as social commitment and thoughtfulness $(\beta=0.07, p \leq 0.01)$ and negatively correlated with the idea of excellence as conformity $(\beta=-0.14, p \leq 0.05)$. In other words, students who are regular readers do not share a conformist vision on excellence. One possible explanation for this is that, through books, students find an alternative space of school culture, thereby not restricting excellence to the knowledge imparted in spaces of formal education. Another interesting factor to explain perceptions of excellence is "political or social participation" which has a similar impact on students' perceptions on excellence as reading does, i.e., it has a positive and significant relation with perceptions of excellence as social commitment and thoughtfulness $(\beta=0.12, p \leq$ $0.1)$ and a negative correlation with excellence as conformity $(\beta=$ $-0.14, p \leq 0.1)$. The variable "leisure and spending time with the family" is correlated with more conservative perceptions of excellence: as academic development $(\beta=0.27, p \leq 0.05)$ and as effort and self-improvement $(\beta=0.18, p \leq 0.05)$, which is also positively related with sports enrollment $(\beta=0.06, p \leq 0.01)$.

Finally, concerning students' perceptions about their current school, the construct excellence as feeling stressed and giving up social life is influenced by three variables: the perception of their school as being "too obsessed with students' grades" $(\beta=0.15, p \leq$ $0.01)$, as "recognizing excellence and merit above all things" $(\beta=$ $0.08, p \leq 0.1$ ), and as "motivating them to take part in extracurricular activities" ( $\beta=0.06, p \leq 0.05)$. This might be related to pressure on students to generate good test results and to balance curricular and extracurricular activities that take up the students' limited free time, increasing their perception of excellence as a sacrifice of their leisure time (Glasman, 2005).

However, the same school characteristics described in the former independent variables also have a correlation with other positive perceptions on excellence, which may prove that the same school characteristic can be evaluated positively or negatively by students. For instance, attending a school that "recognizes excellence and merit above all things" can be seen as an educational support rather than as a stressful obligation. So, it is understandable that this variable is positively correlated with the idea of excellence as academic development $(\beta=0.16, \mathrm{p} \leq$ $0.01)$. Similarly, the variable "schools are too obsessed with students' grades" and "they value merit and excellence above all other things" has a positive and significant correlation with excellence as effort and self-improvement $(\beta=0.13, p \leq 0.01$ and $\beta=0.09, p \leq 0.1$, respectively). This finding suggests that the pressure exerted by establishments can instill in their students the idea that effort and self-improvement are two fundamental factors in attaining excellence.

Lastly, still regarding school variables, there is also a significant and positive correlation between the perception of excellence as 
social commitment and thoughtfulness and the recognition of school as an establishment that "recognizes my efforts" $(\beta=0.05$, $p \leq 0.05)$ and "motivates my involvement in extracurricular life" ( $\beta$ $=0.08, p \leq 0.01)$. This implies that the expressive notion of excellence is important in schools where we can find programs that not only seek to recognize and foster the talents of the best students (through awards and honor rolls, among others), but also provide direct encouragement for student participation in extracurricular activities.

\section{CONCLUSION}

The purpose of this research was to study the notions of excellence shared by students enrolled in a group of HighPerforming Public Schools in Chile, and to analyze the factors related to these perceived notions. In line with our general hypothesis, results show that student perceptions of excellence are related to issues beyond the school and family frameworks, and are related to instrumental and expressive dimensions, generating a polysemous understanding of this concept (Duru-Bellat and Mingat, 2011). The results also showed that the various notions of excellence are explained by several factors. On one hand, students who associate excellence with self-improvement and surpassing one's own achievements are those who have the highest expectations for their academic and professional success. On the other hand, students with a negative view of excellence (associated with stress and abnegation) profess the intention to have a life without projects and based on "laissezfaire". Lastly, students with more conservative school practices and life perspectives are the ones who most associate excellence with conformity and performance, while students who currently participate more in political and associative life, and who intend to do so in the future, are the ones who most associate excellence with commitment.

These findings have important implications for public policy and educational research on high-performing schools and gifted students. In terms of public policy, the results invite more nuanced discussion on the value and purpose of HPPS. Given the current HPPS restructuring and the decline in HPPS enrollment in Chile, these schools will have a different role to that held in the country for more than 100 years. This study -showing the centrality of merit in the construction of excellenceallow to re-evaluate the purpose of these schools, giving way to the design of new curricula that will allow these schools to be a vehicle for social mobility but, at the same time, to be a place of experimentation and creation, welcoming students with multiple abilities and interests. In this line, the results of the study shed light on the transformations that could be introduced in HPPS in the coming years.

This work can also contribute to knowledge on HPPS, which have been analyzed in dimensions that are detached from student subjectivities. These schools' admissions criteria (Allensworth et al., 2016), the higher probability of being accepted to an elite university (Mansfield, 2019; Dickson and Macmillan, 2020), the impact of these establishments on school segregation processes (Gorard and Siddiqui, 2018) and the organizational practices adopted by these schools (Moraes et al., 2020) have been the most common topics related to HPPS research, to date. This article is therefore a valuable contribution to those studies, introducing HPPS student perceptions of excellence into the discussion-a significant current subject of discussion.

Related to the field of education research, the results permit a deeper exploration of the relationships between individual perceptions of excellence and structural educational dynamics. The results of the study allow thinking about how the projects of excellence imposed by educational establishments are perceived by students within those establishments. Taking into consideration the experiences and opinions shared by students -as well as by teachers and directors- regarding the different processes occurring in the educational field is important to sociological discussion on school culture and educational assessment. In this sense, the results of the study pose the question about one of the least-studied educational aspects in the last decades: what is the distance between institutional projects and the aspirations or perceptions of the students?

As with any other research, this study has some limitations that are important to recognize. First, the analysis developed in this investigation uses the results of a cross-sectional survey based on specific items intentionally built to capture the extreme opinions on notions of excellence by the surveyed students. Thus, these results do not clarify what changes occur in the concept of excellent throughout school life. Secondly, the questionnaire focused only on a few grades and only considered students, which excludes the analysis of how excellence is formed in the initial years and how the directors understand excellence. Thirdly, this research is only focused on one kind of school (HPPS) and a specific student profile (those belonging to middle-upper and upper classes), which does not allow any kind of dialogue or data comparison between privileged versus underprivileged students. Moreover, there are no studies in Chile that discuss students' perceptions on excellence in other school contexts, which could have been useful to our data analysis and to contrast to our results with. Future research may find it relevant to complement our results with other school contexts. Other areas of extension include comparison with qualitative findings on excellence, in order to analyze the subjectivities experienced by students and by other educational actors (teachers, principals and parents), and identifying similarities and differences among these perceptions.

Lastly, although the Chilean educational system can be understood as an exceptional case study due to the centrality of a market-oriented educational system, these results can motivate educational and sociological discussions in other countries. The tensions between "public schools and equal opportunities" and "principles of excellence and merit" are, indeed, a major issue of concern in global educational contexts. It would be interesting and useful to promote and encourage comparative studies that investigate these types of schools in different cultural contexts that contrast with Chile's and that analyze how the concept of excellence changes according 
to the organizational, ideological, and political orientations of various educational systems.

\section{DATA AVAILABILITY STATEMENT}

The raw data supporting the conclusions of this article will be made available by the authors, without undue reservation.

\section{ETHICS STATEMENT}

Ethical review and approval was not required for the study on human participants in accordance with the local legislation and institutional requirements. Written informed consent to

\section{REFERENCES}

Alarcón, C. (2017). "Class Isolation: Examining Private Schools in Chile," in Private Schools and School Choice in Compulsory Education. Editor T. Koinzer. (Wiesbaden: Springer), 99-114.

Allende, C. (2015), Efectividad de los Liceos Públicos Selectivos de Excelencia en Chile [Effectiveness in high-performing and selective public schools], Master Thesis, Chile: University of Chile. Available at: http://repositorio.uchile.cl/ bitstream/handle/2250/134591/Efectividad\%20de\%20los\%20liceos\%20p\%C3\% BAblicos\%20de\%20excelencia\%20en\%20Chile.pdf?sequence=1.

Allensworth, E. M., Moore, P. T., Sartain, L., and de la Torre, M. (2016). The Educational Benefits of Attending Higher Performing Schools: Evidence from Chicago High Schools. Educ. Eval. Pol. Anal. 39 (2), 175-197. doi:10.3102/ 0162373716672039

Angrist, J. D., and Rokkanen, M. (2015). Wanna Get Away? Regression Discontinuity Estimation of Exam School Effects Away from the Cutoff. J. Am. Stat. Assoc. 110 (512), 1331-1344. doi:10.1080/01621459.2015.1012259

Aubert, N., and Gaulejac, V. (1991). Le Coût de l'Excellence [The price of excellence]. Paris: Éditions Seuil.

Bailey, R., Pearce, G., Smith, C., Sutherland, M., Stack, N., Winstanley, C., et al. (2012). Improving the Educational Achievement of Gifted and Talented Students: A Systematic Review. Talent Dev. Excell. 4 (1), 33-48.

Ball, S., Maguire, M., and Braun, A. (2012). How Schools Do Policy. Policy Enactments in Secondary Schools. New York: Routledge.

Barker, B., and Hoskins, K. (2017). Can High-Performing Academies Overcome Family Background and Improve Social Mobility? Br. J. Sociol. Edu. 38 (2), 221-240. doi:10.1080/01425692.2015.1073104

Bellei, C. (2015). El gran experimento. Mercado y privatización de la educación chilena. [The big experiment. Market and privatization of Chilean education]. Santiago: LOM Ediciones.

Bellei, C., González, P., and Valenzuela, J. (2010). ““Fortalecer la educación pública: un desafío de interés nacional". [Strengthening public education: a national interest challenge]," in Ecos de la Revolución Pingüina. Avances, desafíos y silencios de la reforma educacional [Echoes from the Penguin Revolution. Advances, debates and silences in the educational reform]. Editors C. Bellei, D. Contreras, and J. Valenzuela (Santiago: Pehuén), 225-256.

Berger, R. (2003). An Ethic of Excellence. Building a Culture of Craftsmanship with Students. Heinemann.

Bourdieu, P. (1998). La Domination Masculine [Masculine Domination]. Paris: Éditions du Seuil.

Brown, P., Power, S., Tholen, G., and Allouch, A. (2016). Credentials, talent and Cultural Capital: a Comparative Study of Educational Elites in England and France. Br. J. Sociol. Edu. 37 (2), 191-211. doi:10.1080/01425692.2014.920247

Bucarey, A., Jorquera, M., Muñoz, P., and Urzúa, S. (2014). El efecto del Instituto Nacional: Evidencia a partir de un diseño de regresión discontinua [The effect of Instituto Nacional: evidence from a regression discontinuity design]. Estudios Públicos 133, 37-68. doi:10.38178/cep.vi133.252 participate in this study was provided by the participants' legal guardian/next of kin.

\section{AUTHOR CONTRIBUTIONS}

MQ. Conceptualization, Formal analysis; Investigation; Methodology; Project administration; Supervision; Writing-original draft; Writing-review and editing. CA Conceptualization; Data curation; Formal analysis; Investigation; Methodology; Writing-original draft; Writing-review and editing. CV Conceptualization; Formal analysis; Methodology; Investigation; Writing_original draft; Writing-review and editing. SA Investigation; Writing—original draft; Writing—review and editing.

Carrasco, A., Contreras, D., Elacqua, G., Mizala, A., Santos, H., Torche, F., et al. (2014). Hacia un sistema escolar más inclusivo. Cómo reducir la segregación escolar en Chile [Towards a more inclusive educational system. How to reduce academic segregation in Chile]. Santiago: Unesco.

Castillo, D., Santa Cruz-Grau, E., and Vega, A. (2018). Estudiantes migrantes en escuelas públicas chilenas. Cal Edu (49), 18-49. doi:10.31619/caledu.n49.575

Castillo, I. (2017). La revolución de los pingüinos: Educational Reforms and the Chilean Winter. South Bend Undergraduate Res. J. 17, 159-170.

Clark, D. (2010). Selective Schools and Academic Achievement. B.E. J. Econ. Anal. Pol. 10 (1), 1-40. doi:10.2202/1935-1682.1917

Courtois, Aline. (2018). Elite Schooling and Social Inequality. Privilege and Power in Ireland's Top Private Schools. London: Palgrave Macmillan.

Cox, C., and Imbarack, P. (2017). "Catholic Elite Education in Chile: Worlds Apart," in Catholic Education in the Wake of Vatican II. Editors J. Rosa Bruno and J. Igelmo Zaldivar (Toronto: University of Toronto Press).

Cress, C., Burack, C., Giles, D., Elkins, J., and Stevens, M. (2010). Promising Connection: Increasing College Access and success through Civic Engagement. Minneapolis: Campus Compact.

Darmon, M. (2013). Classes Préparatoires. La Fabrique D'une Jeunesse Dominante [Preparatory Classes. The Making of a Dominant Youth]. Paris: La Découverte.

Delgado, F. (2019). Vuelve a bajar la cantidad de postulantes que buscan ingresar al Instituto Nacional en 2020. Biobiochile.cl. Available at: https:/www. biobiochile.cl/noticias/nacional/region-metropolitana/2019/10/02/vuelve-abajar-la-cantidad-de-postulantes-que-buscan-ingresar-al-instituto-nacionalen-2020.shtml.

Dickson, M., and Macmillan, L. (2020). Social Mobility and Higher Education: Are Grammar Schools the Answer? Higher Education Policy Institute Occasional Paper Series. Retrieved from https://purehost.bath.ac.uk/ws/portalfiles/portal/ 203701020/Social_Mobility_and_Higher_Education_Are_grammar_schools_ the_answer.pdf.

DiStefano, C., Zhu, M., and Mindrila, D. (2009). Understanding and Using Factor Scores: Considerations for the Applied Researcher. Pract. Assess. Res. Eval. 14, 1-11. doi:10.7275/da8t-4g5210.1093/envhis/14.3.476

Dobbie, W., and Fryer, R. G. (2014). The Impact of Attending a School with HighAchieving Peers: Evidence from the New York City Exam Schools. Am. Econ. J. Appl. Econ. 6 (3), 58-75. doi:10.1257/app.6.3.58

Donoso, S. (2013). Dynamics of Change in Chile: Explaining the Emergence of the 2006 Pingüino Movement. J. Latin Am. Stud. 45 (01), 1-29. doi:10.1017/ s0022216x12001228

Duru-Bellat, M., and Mingat, A. (2011). "Measuring Excellence and Equity in Education, Conceptual and Methodological Issues," in Equity and Excellence in Education: Towards Maximal Learning Opportunities for All Students. Editors K. Van den Branden, P. Avermaet, and M. Houtte (New York: Routledge), 21-38.

Dustan, A. (2010). Have Elite Schools Earned Their Reputation?: High School Quality and Student Tracking in Mexico City. University of California. Available at: https://are.berkeley.edu/fields/ae/dustan.pdf. 
Fercovic, M. (2020). Disentangling Meritocracy Among the Long-Range Upwardly Mobile: The Chilean Case. Sociological Res. Online, 136078042096339-18. Sociological Research Online, Special Section: Making Sense of Social Mobility in Unequal Societies. doi:10.1177/1360780420963395

Finn, C., and Hockett, J. (2012). Exam Schools: Inside America's Most Selective Public High Schools. Princeton: Princeton University Press.

Gillies, D. (2007). Excellence and Education: Rhetoric and Reality. Educ. knowledge economy 1 (1), 19-35. doi:10.1080/17496890601128209

Glasman, D. (2005). Leur reste t-il du temps pour jouer? [Do they have yet time to play? Diversité: Ville école Intégration 141, 51-57. Available at: http://www2. cndp.fr/lesScripts/bandeau/bandeau.asp?bas=http://www.cndp.fr/RevueVEI/ accueil.htm.

Godoy, F., Salazar, F., and Treviño, E. (2014). Prácticas de selección en el sistema escolar chileno: tipos de requisitos de postulación, legitimación en el sistema y las debilidades de la ley [Selection practices in the chilean school system: types of requirements to postulate, legitimation in the system and weaknesses of the law]. Report for Centro de Políticas Comparadas de Educación. Santiago de Chile: University Diego Portales.

Gopinathan, S., and Lee, M. H. (2018). Excellence and equity in high-performing education systems: policy lessons from Singapore and Hong Kong / Excelencia y equidad en sistemas educativos de alto rendimiento: lecciones de las políticas educativas en Singapur y Hong Kong. Infancia y Aprendizaje 41 (2), 203-247. doi:10.1080/02103702.2018.1434043

Gorard, S., and Siddiqui, N. (2018). Grammar Schools in England: a New Analysis of Social Segregation and Academic Outcomes. Br. J. Sociol. Edu. 39 (7), 909-924. doi:10.1080/01425692.2018.1443432

Hair, J., Black, W., Babin, B., and Anderson, R. (2010). Multivariate Data Analysis. Prentice-Hall.

Hartley, D. (2006). Excellence and Enjoyment: the Logic of a 'Contradiction'. Br. J. Educ. Stud. 54 (1), 3-14. doi:10.1111/j.1467-8527.2005.00331.x

Huang, C. (2011). Self-concept and Academic Achievement: a Meta-Analysis of Longitudinal Relations. J. Sch. Psychol. 49, 505-28. doi:10.1016/ j.jsp.2011.07.001

Humphreys, L. G., and Montanelli Jr., R. G. (1975). An Investigation of the Parallel Analysis Criterion for Determining the Number of Common Factors. Multivariate Behav. Res. 10, 193-205. doi:10.1207/s15327906mbr1002_5

Kirabo Jackson, C. (2010). Do Students Benefit from Attending Better Schools? Evidence from Rule-based Student Assignments in Trinidad and Tobago. Econ. J. 120 (549), 1399-1429. doi:10.1111/j.1468-0297.2010.02371.x

MacAllister, J., MacLeod, G., and Pirrie, A. (2013). Searching for Excellence in Education: Knowledge, Virtue and Presence? Ethics Edu. 8 (2), 153-165. doi:10.1080/17449642.2013.843964

Madrid, S. (2016). “"Diversidad sin diversidad: Los colegios particulares pagados de elite y la formación de la clase dominante en una sociedad de mercado" ["Diversity without diversity: elite private schools and upper class education in a market society"]," in Mercado Escolar Y Oportunidad Educacional: Libertad, Diversidad Y Desigualdad [School Market and Educational Opportunity: freedom, Diversity and Inequality]. Editors J. Corvalán, A. Carrasco, and J. García-Huidobro (Santiago de Chile: Ediciones Universidad Católica), 269-299.

Mansfield, I. (2019). The Impact of a Selective Secondary Education on Progression to Higher Education. Occasional paper 19. Retrieved from https://www.hepi.ac. uk/wp-content/uploads/2019/01/HEPI-Occasional-Paper-19-as-publishedScreen.pdf.

Marsh, H. W., Kuyper, H., Morin, A. J. S., Parker, P. D., and Seaton, M. (2014). Bigfish-little-pond Social Comparison and Local Dominance Effects: Integrating New Statistical Models, Methodology, Design, Theory and Substantive Implications. Learn. Instruction 33, 50-66. doi:10.1016/ j.learninstruc.2014.04.002

Marsh, H. W., and Parker, J. W. (1984). Determinants of Student Self-Concept: Is it Better to Be a Relatively Large Fish in a Small Pond Even if You Don't Learn to Swim as Well? J. Personal. Soc. Psychol. 47 (1), 213-231. doi:10.1037/00223514.47.1.213

Matthews, D. J., and Dai, D. Y. (2014). Gifted Education: Changing Conceptions, Emphases and Practice. Int. Stud. Sociol. Edu. 24 (4), 335-353. doi:10.1080/ 09620214.2014 .979578
Matthews, D., and Kitchen, J. (2007). School-Within-a-School Gifted Programs. Gifted Child. Q. 51 (3), 256-271. doi:10.1177/0016986207302720

Mension-Rigau, E. (2007). Aristocrates et grands bourgeois [Aristocrats and high bourgeois]. Paris: Éditions Plon.

Moraes, J., Manoel, M. V., Batista Dias, B. F., and Holanda Mariano, S. R. (2020). Prácticas Organizativas en las Escuelas Públicas de Alto Rendimiento en Brasil. Reice 18 (1), 5-25. doi:10.15366/reice2020.18.1.001

Moya Díaz, E., and Hernández Aracena, J. (2014). El Rol de los Colegios de Elite en la Reproducción intergeneracional de la Elite Chilena. Rev.Austral.Cienc.Soc 26, 59-82. doi:10.4206/rev.austral.cienc.soc.2014.n26-04

Müller, C., and Zurbriggen, C. (2016). An Overview of Classroom Composition Research on Social Emotional Outcomes - Introduction to the Special Issue. J. Cogn. Edu. Psychol. 15, 163-184. doi:10.1891/1945-8959.15.2.163

Neild, R. C. (2004). The Effects of Magnet Schools on Neighborhood High Schools: An Examination of Achievement Among Entering Freshmen. J. Edu. Students Placed Risk (Jespar) 9 (1), 1-21. doi:10.1207/s15327671espr0901_1

Perrenoud, P. (1995). Ofício de aluno e sentido do trabalho escolar [The student's job and the sense of school work]. Porto: Porto Editora.

Peters, S. J., and Engerrand, K. G. (2016). Equity and Excellence. Gifted Child. Q. 60 (3), 159-171. doi:10.1177/0016986216643165

Plucker, J. A., and Callahan, C. M. (2014). Research on Giftedness and Gifted Education. Exceptional Child. 80 (4), 390-406. doi:10.1177/0014402914527244

Quaresma, M. (2014). Entre o herdado, o vivido e o projetado. Estudo de caso sobre o sucesso educativo em dois colégios privados frequentados pelas classes dominantes [Between inheritance, life experience and expectations: case study about educational success in two private schools attended by upper classes]. Porto: Edições Afrontamento.

Rabe-Hesketh, S., and Skrondal, A. (2008). Multilevel and Longitudinal Modeling Using Stata. Örebro: Stata Press.

Raveaud, M., and Zanten, A. v. (2007). Choosing the Local School: Middle Class Parents' Values and Social and Ethnic Mix in London and Paris. J. Edu. Pol. 22 (1), 107-124. doi:10.1080/02680930601065817

Ruiz, C. (2010). De la República al Mercado. Ideas educacionales y política en Chile. [From Republic to Market, Educational Ideas and Politics in Chile]. Santiago: LOM Ediciones.

Sánchez, M.-D., and Peralta, F. (2003). Associative and Predictive Relationships between Self-Concept and Academic Achievement in Students of Primary Education. Electron. J. Res. Educ. Psychol. 1 (1), 95-120.

Seaton, M., Marsh, H. W., and Craven, R. G. (2010). Big-Fish-Little-Pond Effect. Am. Educ. Res. J. 47, 390-433. doi:10.3102/0002831209350493

Serrano, S., Ponce de León, M., and Rengifo, F. (2012). Historia de la educación en Chile: 1810-2010. Aprender a leer y escribir (1810-1880) [History of education en Chile: 1810-2010. Learning to read and write (1810-1880. Santiago: Taurus.

Sewasew, D., and Schroeders, U. (2019). The Developmental Interplay of Academic Self-Concept and Achievement within and across Domains Among Primary School Students. Contemp. Educ. Psychol. 58, 204-212. doi:10.1016/ j.cedpsych.2019.03.009

Tabachnick, B., and Fidell, L. (2007). Using Multivariate Statistics. 5th ed. Boston: Pearson Allyn and Bacon.

Tryfos, P. (1998). Methods for Business Analysis and Forecasting: Text and Cases. New Jersey: John Wiley \& Sons.

UNICEF (2014). La Voz del Movimiento Estudiantil 2011.Educación Pública, Gratuita $y$ de Calidad [The voice of the student mobilisation 2011. For free and quality public education. Santiago: UNICEF.

Valenzuela, J.-P., and Allende, C. (2012). "Logros en Liceos Públicos de Excelencia en Chile: valor agregado o solo descreme de la elite? [High Public Performing Schools achievement in Chile: added value or just elite cream skimming?] [Paper]," in II Congreso Interdisciplinario de Investigación en Educación CIIE (Santiago, Chile.

Van Avermaet, P., Van Houtte, M., and Van den Branden, K. (2011). "Promoting Equity and Excellence in Education: an Overview," in Equity and Excellence in Education: Towards Maximal Learning Opportunities for All Students. Editors K. Van den Branden, P. Avermaet, and M. Houtte (New York: Routledge), 1-20.

Villalobos, C., and Quaresma, M. (2015). Sistema escolar chileno: Características y consecuencias de un modelo orientado al mercado [Chilean school system: 
characteristics and consequences of a market-oriented model]. Convergencia. Revista de Ciencias Sociales 69, 63-84. doi:10.29101/crcs.v22i69.3634

Wolff, F., Nagy, N., Helm, F., and Möller, J. (2018). Testing the Internal/external Frame of Reference Model of Academic Achievement and Academic SelfConcept with Open Self-Concept Reports. Learn. InstructionInstr 55, 58-66. doi:10.1016/j.learninstruc.2017.09.006

Wright, B., Ford, D., and Young, J. (2017). Ignorance or Indifference? Seeking Excellence and Equity for Under-represented Students of Color in Gifted Education. Glob. Edu. Rev. 4 (1), 45-60.

Conflict of Interest: The authors declare that the research was conducted in the absence of any commercial or financial relationships that could be construed as a potential conflict of interest.
Publisher's Note: All claims expressed in this article are solely those of the authors and do not necessarily represent those of their affiliated organizations, or those of the publisher, the editors, and the reviewers. Any product that may be evaluated in this article, or claim that may be made by its manufacturer, is not guaranteed or endorsed by the publisher.

Copyright (c) 2022 Quaresma, Allende, Villalobos and Araneda. This is an openaccess article distributed under the terms of the Creative Commons Attribution License (CC BY). The use, distribution or reproduction in other forums is permitted, provided the original author(s) and the copyright owner(s) are credited and that the original publication in this journal is cited, in accordance with accepted academic practice. No use, distribution or reproduction is permitted which does not comply with these terms. 